\title{
'REMEMBERING' SINDH, RECONSTRUCTING SINDH: THE POLITICS OF MEMORY AMONG SINDHI HINDUS IN INDIA
}

\author{
Nandita Bhavnani \\ Independent Scholar
}

\begin{abstract}
When India was partitioned in 1947, the province of Sindh went in its entirety to the newlyformed state of Pakistan. The bulk of the Hindus (and Sikhs) of Sindh migrated to India in the months that followed. Given that there was no part of Sindh in India, and given the harsh visa regime shared by the two countries, Sindhi Hindus have had little or no contact with their original homeland for the last seven decades. Some among the generations of Sindhi Hindus that migrated to India (and subsequently formed the diaspora) have shared their recollections with their children and grandchildren. There has been a corresponding move among a section of Sindhi Hindus to distance themselves from memories of a culture shared with Muslims, and a history that was largely dominated by Muslims. Yet, as is the case with many communities, Sindhi Hindus too feel the need for a community history. Consequently, when Sindhis recall Sindh, they often refer to a 'sanitized' Sindh, which they have supposedly 'inherited'.
\end{abstract}

Keywords: collective memory, Hindu, Muslim, Partition, Sindh, Sindhi history.

\section{RESUMEN}

Con la división de la India británica en 1947, toda la provincial de de Sindh pasó a formar parte de Paquistán, y la mayoría de los hindúes (y sijs) de Sindh emigraron a India en los meses siguientes. Puesto que ninguna parte de Sindh pasó a la nueva India y el régimen de visados entre esta y Paquistán era muy estricto, los hindúes procedentes de esa región han tenido poco contacto directo con ella. Una parte de quienes migraron a India (y en última instancia formaron parte de la diáspora) han transmitido sus recuerdos a sus descendientes. Se puede entrever que han relegado la cultura que compartían con sus vecinos musulmanes a un lugar secundario, así como la historia de su región, mayormente dominada por el poder islámico. Sin embargo los sindhis, como otras muchas comunidades, tienen la necesidad de construir una historia 'heredada', muchas veces 'purgada' de factores adversos.

Palabras clave: Memoria colectiva, hindúes, musulmanes, la Partición, Sindh, Historia de los sindhis. 
Jiye munhinji Sindh,

Maan ta ghoriyaan penhinji jind

Penhinje abaarne vatan taan!

Abaarne vatan taan,

Sindh je chaman taan,

Jiye munhinji Sindh...

Kiyan visaryaan Sindh ja nazaara

Sadhbele Manorhe vaara

Chand jyun raatyun ain behraarna

Lal ja panjda gayindar muhaarna Jiye munhinji Sindh...

Sufiyan santan ji aahe Sindhri Mast faqiran ji aahe Sindhri

Shah Sachal Sami-a jo dero

Shaal vanya ute aaun bik bhero Jiye munhinji Sindh...

Mohan jo daro jehinji nishaani Jeko na samjhe kare tho naadaani Jeko bi Sindh visaararn chaahe Sacho sapoot so Sindh jo naahe Jiye munhinji Sindh... Marui-a vaaangur piyo baadaayaan Ajhaa abaarna shaal vasaayaan
Long live my Sindh

I would gladly give my life

For my ancestral land!

For my ancestral land,

For the garden that is Sindh

Long live my Sindh...

How can I forget the sights of Sindh

Those of Sadhbela and Manora ${ }^{1}$

New moon nights and ritual offerings to the river $\operatorname{god}^{2}$

Muhanas singing praises of [Jhule] $\mathrm{Lal}^{3}$

Long live my Sindh...

My beloved Sindh is [the land] of Sufi saints

My beloved Sindh is [the land] of ascetics lost in a trance

The home of Shah, Sachal and Sami ${ }^{4}$

May I go there once again

Long live my Sindh...

Its symbol is Mohan jo daro [sic] ${ }^{5}$

Whoever doesn't understand this, errs

Whoever wants to forget Sindh

Is not a true son of Sindh

Long live my Sindh...

I lament like Marui ${ }^{6}$

May I settle down again

${ }^{1}$ Both these are sites of Hindu temples in Sindh.

2 Behraanas, or ritual offerings to the river god, were generally made on the day of the new moon.

${ }^{3}$ Muhanas are an ancient tribe of Muslim fishermen and ferrymen in Sindh. Many of them live in houseboats. They revere the water, which is their home and the source of their livelihood, and are known to have faith in the river deity, known as Khwaja Khizr to the Muslims, or Jhule Lal to the Hindus, or Zinda Pir to both Hindus and Muslims.

${ }^{4}$ Shah Abdul Latif Bhitai (1689-1752) and Sachal Sarmast (1739-1829) were both Muslim poet-saints. Chainrai Bachomal 'Sami' (1743-1850) was a Hindu merchant in Shikarpur, who synthesized Sufi and Vedantic thought in his poetry. Together, these three names form the triumvirate of Sindhi Sufi poetry.

${ }^{5}$ Moenjodaro, Sindhi for 'the mound of the dead', is often misspelt as Mohenjodaro or Mohan jo daro, meaning, 'the mound of Mohan', sometimes further wrongly interpreted to mean 'the mound of Krishna'. Ironically, often Sindhis themselves commit this mistake.

${ }^{6}$ Marui is the heroine of a well-known Sindhi legend. A beautiful village belle, Marui was abducted by Umar, the king of Umarkot, who wished to marry her. But Marui remained constant to her fiancé, to her community, and to her own land, and thus became a byword for loyalty and patriotism. 
Jhularn Asha kando hia poori

Jhumariyun payindas umar samoori

Jiye munhinji Sindh...
$J_{h u l a n}^{7}$ will fulfil this hope of mine ${ }^{8}$

I will dance [his praises] all my life

Long live my Sindh...

(Chawla and Thakur 61)

\section{THE CONTEXT FOR THE SONG}

This Sindhi song was written by the late Sindhi film director, actor and writer, Dharam Kumar Tolani (1919-1993), whose pen name was 'Deepak Asha'. Its intended audience was probably Sindhi Hindus in India or in the diaspora, who had migrated from Sindh after the Partition of India in 1947. The song seeks to not only memorialize, but also celebrate, Sindh, the poet's 'ancestral land'.

After the Partition of India in 1947, when Sindh became a part of Pakistan, the bulk of its minorities chose to migrate to India. While it is not possible to arrive at the exact number of the Hindus and Sikhs who migrated from Sindh in 194748, it has been estimated at approximately 1 million people (Bhavnani 162; Boivin and Rajpal 45). ${ }^{9}$ In India, these Sindhi Hindus were scattered mostly across western India. During the colonial period, some Sindhi Hindu traders and merchants were living abroad for business purposes, and in the years after Partition, this diaspora not only became cemented, but also grew exponentially, both in numbers as well as in distribution.

In the early years after Partition, Sindhi Congress leaders, such as Dr Choithram Gidwani and Jairamdas Doulatram, had strongly advocated that Sindhi Hindu refugees should learn local languages and adapt to local cultures and assimilate in local populations, wherever they resettled. This was bolstered by the then-prevalent Nehruvian ideology of Indian citizens rising above their ethnic affiliations and religions to unite as 'Indians'.

However, there were also some Sindhis like the professor, writer and community leader, Ram Panjwani, Deepak Asha and others, who battled these trends to dilute Sindhi identity by exhorting Sindhis to keep their language and cultural identity alive. According to the writer Bhagwan Bhagchandani, 'Deepak Asha' (like Ram Panjwani) toured Sindhi Hindu refugee camps and resettlement colonies in those early years after Partition. They entertained Sindhi Hindus with music, while encouraging them not to forget their Sindhi culture and identity. It is likely that this song was written during this early period of resettlement, and with such a purpose.

7 Diminutive term for Jhule Lal.

${ }^{8}$ The poet puns on his hope for the community, and his pen name 'Asha' which also means 'hope', and traditionally appears in the last verse of the poem.

9 It should be remembered that minorities have continued to migrate from Sindh to India and other countries through the intervening decades, albeit in much smaller numbers. 
While Deepak Asha's hopes for a robust sense of ethnic identity among Sindhis in India may have had limited success, his song became highly popular at Sindhi gatherings. Over the intervening decades, it has been sung or played at numerous Sindhi events. However, it is a highly selective representation of, or 'remembering' of, Sindh.

The song portrays a somewhat 'Hindu-ized' Sindh. It refers to only Hindu places of worship, such as Sadhbelo and Manora, and also the ritual offering of the bahraana on days of the new moon.

What is interesting is that although Sindh had a predominantly Muslim population and history, these have been largely ignored in the song. Muslims formed a majority of $76 \%$ of Sindh's population according to the 1941 census. (Lambrick 17). Further, Sindh had been under continuous Muslim rule for roughly eleven centuries, from the invasion of Muhammad bin Qasim in 711-713 CE until the British conquest in 1843. Consequently, most of the antique architectural remains found in Sindh are Muslim in style and origin. Traditionally, Sindhi handicrafts and textiles have also been produced mostly by Muslim artisans. However, the song clearly underplays the considerable Muslim presence in Sindh. It mentions Sindhi Muslims in a highly selective manner, and highlights only those elements of Sindhi history and culture that Hindus can easily identify with.

The song refers to Muhanas, the marginalized Sindhi Muslim community of fishermen and ferrymen, but only in the context of their singing praises of Jhule Lal, the god of the river Indus. It also refers to Marui, the Muslim heroine of a Sindhi legend, famous for her loyalty to her homeland while in forced exile (here Marui is invoked as an ideal or as an allegory, for those Sindhi Hindus who still yearn for their homeland.) The only other Sindhi Muslims mentioned in the song are the famous Sufi poet-saints, Shah Abdul Latif Bhitai (1689-1752) and Sachal Sarmast (1739-1829). Finally, the poet invokes Moenjodaro as the ultimate symbol of Sindh.

The poet also makes two ironic claims. Firstly, he asserts that anyone who wants to forget Sindh is not a true son of Sindh, despite himself disregarding the not-inconsiderable Muslim aspects of Sindh in this very song. And secondly, he repeatedly claims that he would gladly give his life for Sindh, but actually the opposite appears to be true, since he himself migrated to India. ${ }^{10}$

Using this song as a springboard, this essay proposes to delineate motifs that recur in this selective 'remembering' of Sindhi history. It further examines possible causal factors in pre-1947 Sindhi society as well as post-Partition developments that possibly contributed to this reconstruction of Sindhi history.

10 Born in 1919, Deepak Asha would have been a 28 year-old adult in 1947, and not a child, subject to the decisions of his parents. 


\section{A SELECTIVE 'REMEMBERING' OF SINDH}

The selective 'remembering' of the Sindh portrayed in this particular song is a symptom of the Sindhi Hindu community's 'remembering' of Sindh in general, which has been borne out in the community's popular writings on Sindh and its history. ${ }^{11} \mathrm{~A}$ few salient tropes stand out.

\section{A. An 'Aryan' Moenjodaro}

Firstly, a salient feature of this Sindh 'remembered' by Sindhi Hindus is that of Moenjodaro and the Harappa, or the Indus Valley, civilization. Notwithstanding archaeological research and academic findings that state that it is not yet possible to conclusively prove the identity of the inhabitants of this civilization, numerous Sindhi Hindus choose to believe that the denizens of this ancient culture were Aryans, who were also the authors of the Vedas, and therefore the founders of Hinduism (and also the ultimate ancestors of the Sindhis of today).

A prominent example of this 'belief' is the popular work of fiction The Return of the Aryans, by Bhagwan S. Gidwani and its subsequent adaptation, The March of the Aryans. ${ }^{11}$ Forgoing any archaeological evidence or other historical proofs, Gidwani holds up Sindh as the birthplace and cradle of Hinduism. In his own words, "This novel tells the story of the Aryans [...] I must present this as a work of fiction. But fiction is not falsehood. Nor a dream. Nor guesswork. Ideally it should be seen as a fictionalized alternative history that our mainstream historians have not attempted to write" (Gidwani 1994: xi). In the same vein, he holds that "... the imperishable remembrance of the Aryan movement and migration from India; and the message in these songs is clear - that the Aryans originated from India and nowhere else" (xi). He also maintains, "The Aryans of $5000 \mathrm{BC}$ were born, grew up and died as Hindus. They were anchored in the timeless foundation of the Hindu tradition" (xii).

While Gidwani's writings are clearly fiction, and as yet are unsupported by any hard proof, they are often assumed as facts by some Sindhis. For example, Gidwani posits that the Aryans originated in "the land of the Sindhu," but dispersed in different directions in $5000 \mathrm{BCE}$ and returned to India centuries later. This has been stated as fact (citing Gidwani's work) by Prem Matlani in The Indus Empire: History of Sindh (21). Again, during a Sindhi seminar-cum-cultural festival titled 'Hojamalo' hosted by Jai Hind College, Mumbai, on 24-25 January 2018, placards were placed around the campus with information on Sindhi history and culture. One such placard quoted Gidwani, and suggested that Hinduism took birth in

${ }^{11}$ Gidwani was the son of Shamdas Gidwani, the pre-Partition head of the right-wing Hindu Mahasabha in Sindh. However, Sindhi Hindu identity can be complex. Gidwani dedicated his book to his two sons, the elder named Manu, possibly after the Hindu lawgiver, and the younger named Sachal, after the Sufi saint. 
Sindh prior to $8000 \mathrm{BCE}$, and that a Sindhi person was the first to chant 'Om', a mantra held sacred by Hindus.

Other Sindhi Hindus have also voiced similar beliefs, and maintain that they are the heirs to the Indus Valley civilization — even though Sindhis, along with the modern world, became aware of this civilization only in the early 1920s. For example:

With Sindhi culture being a synthesis of the Indus Valley and Vedic civilisations, its language also inevitably showed the influence of these cultures (Buxani, 39). ${ }^{12}$

The society of Sindhis [...] is more Aryan and undiluted than the Hindu society in the rest of India. (Thakur, 24).

The origins of the Sindhi community can be traced back to the period of MohanJo-Daro civilization, the oldest in the world. As such Sindhi culture with its deep roots has been a source of inspiration to the community. (Jawhrani, Xv).

\section{B. The 'OpPressor MusLim'}

Secondly, Muslims in general are recalled, or 'reconstructed,' in a negative light, and portrayed as oppressors of Hindus. These generally include Muhammad bin Qasim's invasion of Sindh and the concomitant slaying of Hindus $;{ }^{13}$ as well as the reign of the Talpurs (the last indigenous rulers of Sindh, who were ethnic Baloch Muslims), and their occasional oppression of Hindus. See the following examples:

... I am the dancer of Mohen jo Daro ...

... I am the first and foremost civilization of the world - the epitome of culture The Sindhu Valley civilization in this depleted condition! ...

... Greeks, Turks, Persians, Arabs, all had crossed my land ...

... I remember everything, the foreign invaders, the horses of the savage riders galloping away ...

... I remember everything. They came raising dust storms causing havoc and devastation and crossed my border

From Alexander to Muhammad bin Qasim, from Ghaznavi to Ghori, from Changez Khan to Babar, they played Holi of blood colouring my dust red.

(Quoted in K.N. Vaswani, 82-83)

12 The Indus Valley script remains to be deciphered.

${ }_{13}$ Buddhists are rarely if ever mentioned, even though the majority of Sindh's population at the time was Buddhist. 
... but the Arab invasion [...] brought in wave after wave of foreign hordes. The Tartars, the Arghuns and the Tarkhans, the Moguls, and the Baloch as if the whole world fell upon the country from the west or through the Punjab. And the subsequent history of the Sind Hindus is therefore nothing but a tale of woe of their degradation, conversion and surveillance.

(Thakur, 15-16).

The Sindhis ruled Sind till they were defeated and conquered by the Arabs in the seventh century. And from that time onwards they have played the role of refugees.

(Bharadwaj, 15).

This 'narrative' of Muslims as only 'foreign invaders' and 'oppressors' is at odds with historical facts. Minorities - Hindus, Buddhists and Jains - continued to live in Sindh for centuries after the Arab conquest of Sindh in 711-713 CE. Buddhism declined in Sindh around the $10^{\text {th }}$ century CE, as it did in the rest of India, and Jains remained a numerically small community, who nevertheless lived in Sindh till 1947. Hindus too continued to live, and prosper, in Sindh, and while there may have been migrations eastwards at various points in history, there were also inflows of Hindus from the subcontinent. Different sub-communities of Hindus dominated various Sindhi cities at different points in time, and further, were primarily responsible for the prosperity of these cities. Hindu merchants and traders flourished in the southern Sindh capital of Thatta from the $15^{\text {th }}$ through the $17^{\text {th }}$ centuries. Similarly, Hindu merchants and administrators were actively encouraged to come to Shikarpur by the Durranis, as well as to first Khudabad and later Hyderabad by the Kalhoras, all in the $18^{\text {th }}$ century. These Hindus wielded considerable power and prestige and were patronized and protected (to a large extent) by the Muslim rulers of their cities (Markovits, passim; Allen, 40).

There are also two important exceptions to this anti-Muslim stance: the two eminent Sufi poet-saints, Shah Abdul Latif and Sachal Sarmast. ${ }^{14}$ To begin with, their Sufi poetry and their philosophy of humanism eschew a rigid practice of Islam on the one hand, and on the other, they also embrace Hindus; both these naturally do not antagonize the latter. Consequently, Sindhi Hindus are able to appreciate the heights of excellence reached by the poetry of these two Sufi saints, and are happy to acknowledge them as fellow Sindhis.

Sufism and Sufi practices were widespread in Sindh, among Muslims as well as Hindus, and if the latter visited Sufi dargahs, or became followers of Sufi pirs, these practices were quite socially acceptable in Sindhi Hindu society, and were not frowned upon. Similarly, it was common for Sindhi Hindus to exclaim "Ai Al-

${ }^{14}$ On occasion, other lesser-known Sindhi Muslim Sufi poets — such as Bedil, Bekas and Rohal_- are also cited. See for example, T.L. Vaswani, 44-45; Dhameja, passim. 
lah!" when surprised or startled. As in Deepak Asha's song, we can see that Sindhi Muslims are remembered, but only as Sufis, tolerant of, and acceptable to, Hindus.

\section{The 'Disappearance' of Sindh}

Sindhi Hindus, especially those that migrated during Partition, generally refer to themselves as 'Sindhis', while referring to Sindhi Muslims as jat, the name of a tribe of camel herders, but used derogatorily to denote a crude and illiterate country bumpkin, the Hindu stereotype for all Sindhi Muslims. In turn, Sindhi Muslims refer to themselves as 'Sindhis', while referring to Sindhi Hindus as diwan (meaning minister with reference to older practice of Hindus acting as ministers to the Muslim rulers of Sindh) or vaaniya (meaning merchant or trader). Clearly, prior to 1947, there was little or no sense of an overarching Sindhi provincial identity that transcended religious differences.

At the time of Partition, there was negligible communal violence in Sindh between Sindhi Hindus and Sindhi Muslims. Two anti-Hindu and anti-Sikh pogroms - the first in Hyderabad on 17 December 1947 and the second in Karachi on 6 January 1948 - were perpetrated, largely by Muhajirs who sought property belonging to Sindhi Hindus that became available to them after the latter migrated. These two pogroms were largely responsible for the exodus of Hindus and Sikhs from Sindh. As a result, Sindhi Hindus came to perceive Sindh (and concomitantly Pakistan as well) as a land dominated by Muslims, here they as Hindus had no place and were no longer welcome - and indeed from where they had been forcibly ejected. Consequently, there has been a turning away from Sindh, especially among the younger generation that migrated in 1947-48, and Sindh has been relegated to the past in some ways, at least at a subconscious level. Perhaps this has been a coping mechanism on the part of the Sindhi Hindus, as a means to deal with the trauma of being ejected from their homeland.

This has been reflected in popular writing among and about Sindhis as well. For instance, the writer Kavita Daswani, while describing Sindh, refers to it almost completely in the past tense, as though it ceased to exist after 1947 (Daswani, 5-6). In a similar vein, another writer, Saaz Aggarwal, titled her book Sindh: Stories from a Vanished Homeland; one section in this book is subtitled 'Sindh, the lost homeland: undivided, it vanished' (Aggarwal, 66). However, it must also be said that Aggarwal's book does cover Sindhi history briefly, and also touches upon modern Sindh.

This 'erasure' of Sindh is further aided and accentuated by a statement occasionally made publicly at Sindhi gatherings: Jite Sindhi, hute Sindh , meaning, "Where there are Sindhis, there is Sindh." This is a 'reconstruction' of a new, mobile Sindh (which is composed of only Sindhi Hindus in this context) and the spirit of this statement implies that 'Sindh' - here possibly used as shorthand for a transportable homeland, a place of belonging - exists wherever Sindhi Hindus are to be found, whether in India or in the diaspora.

In tandem with this viewpoint, most Sindhi Hindus are not interested or perhaps even aware of the sociopolitical, cultural or environmental realities of present- 
day Sindh, a land with which they find it difficult to identify today. Further, there is little knowledge or acknowledgement of the relatively small number of Sindhi Hindus that remain in Sindh and the various issues that they face.

\section{EXCEPTIONS}

It should be pointed out that, over the decades, there have been exceptions to this 'selective' remembering of Sindh. After 1947, there was an entire generation of Sindhi Hindu writers in India that wrote extensively about their Partition and post-Partition experiences. Of a literary bent of mind, they were also better informed about Sindhi history. Further, these writers maintained contact with their counterparts and friends in Sindh, and hosted Sindhi Muslim writers and friends who visited them in India. Several of them made journeys back to Sindh, to attend literary conferences, but also to meet their friends and revisit their old homes and hometowns; they published their travelogues subsequently, and almost uniformly had high praise and warmth for their Sindhi Muslim friends.

Moreover, in the two decades spanning the turn of the 21st century (i.e. the 1990s and the 2000s), there were various magazines and journals published, most of which were in English but specifically for a Sindhi readership (given that the Sindhi community had moved away from the Sindhi language and towards English). These include Sindh Sujaag ("Awakened Sindh," in Sindhi) and Sindh Rises (in English), both published by the late Sindhi writer, Kirat Babani (1922-2015), which specifically dealt with various issues faced by Sindhis in Sindh. Other Englishlanguage magazines, such as Aseen Sindhi ("We the Sindhis"), Sindhi International, and Sahyog Times, covered a wide range of subjects such as Sindhi personalities and issues relating to Sindhis in India as well as the historical aspects of various towns and regions of Sindh, apart from various Sindhi legends.

Overall, it appears that a greater interest in Sindhi history, particularly with respect to the eleven centuries of Muslim rule, or actual friendships with Sindhi Muslims, were largely confined to the small community of writers among the Sindhi Hindus.

\section{POSSIBLE CONTRIBUTORY FACTORS}

There were various significant factors that distanced Sindhi Hindus from their history. From interviews with a few of the generation of Sindhi Hindus who were children at the time of Partition, the picture that emerges is that most Sindhi Hindus were not aware of their provincial history in great detail, especially beyond the regimes of the Kalhoras (1737-1783) and the Talpurs (1783-1843). Similarly they were not aware of, or had not visited historical landmarks in Sindh. This was an era of highly undeveloped tourism, in Sindh as well as in other parts of India, when travel was mostly limited to pilgrimages, work-related travel or visits to relatives. It appears that in the pre-Partition period, Sindhi Hindu children were actively kept away by 
their families from visiting Muslim tombs, mausoleums and mosques, although they may have visited Sufi dargahs, which historically have been more welcoming to, and tolerant of, Hindus. Fear of religious conversion was likely a prime cause, as well as an avoidance of sites relating to death (see Bhavnani, xxxi-xxxii)

As a result, it appears that most Sindhi Hindus remained unaware of the richness of the Muslim medieval architecture — tombs and mausoleums, graveyards and mosques - found in Sindh. These architectural sites could have functioned as a means of accessing Sindhi history, and their beauty could have functioned as a gateway to an appreciation of the civilization or historical era that produced that particular monument, and ultimately to a sense of pride in being Sindhi, but sadly, visits to such sites were actively discouraged among Sindhi Hindus.

While some Sindhi Hindus had interactions with, and friends among, Muslims in schools, colleges, offices and neighbourhoods in Sindh, other Sindhi Hindus (especially those from the upper-middle class) recall that their only interaction with Sindhi Muslims was limited to those from the lower-middle class e.g. washermen, butchers, etc. Further, during the first half of the $20^{\text {th }}$ century, Hindu right-wing organizations had put down roots, and acquired a significant presence in Sindh (Kothari, 2006; Bhavnani, xxxix-xlii).

After Partition, Sindhi Hindus distanced themselves to an even greater degree from Sindhi Muslims. This happened for several reasons. Firstly, the subsequent migration from Sindh of a large number of Sindhi Hindus to India (and later to various countries across the globe) resulted in the simple fact of the physical separation from Sindh and Sindhi Muslims, in an era of highly limited communications. This was further cemented by the stringency of the mutual visa regime that subsequently evolved between India and Pakistan, ensuring that Sindhi Hindus would find it difficult if not impossible to visit/revisit Sindh, unless they had relatives living across the border.

Secondly, like other Partition refugees, many Sindhi Hindus chose to blame the trauma of Partition on the 'other' community (Bhavnani, 260-1). As mentioned earlier, it could also have been a coping mechanism to deal with the Partition trauma. Consequently, there was little desire on the part of several Sindhi Hindus to revisit their old homes, which were now occupied by Muslim strangers.

Further, over the many centuries of living under Muslim rule and in a Muslim-majority country, and in the absence of any state patronage for Hinduism, the Hinduism as practised in Sindh was distant from Sanskritic Hinduism in several respects. Sindhi Hindus ate meat and did not practise caste-based untouchability; they sometimes believed in Muslim pirs and visited dargahs; many Hindu schoolchildren learnt Persian and/or Arabic even till 1947, and wrote Sindhi in the Perso-Arabic script, which had Muslim connotations. Sindhi Hindu women wore their traditional dress of suthan-cholo, a tunic worn over trousers, and not the sari or bindi. These various factors served to create the image of the Sindhi Hindu as a 'quasi-Muslim' in the eyes of other Hindus in India, which was especially ironic, considering that the Sindhi Hindus had fled Sindh on the basis of their religion (Balasubrahmanyan, 479-80; Kothari, 116; Nandy, xviii). 
As a result, in an effort to adapt to local societies and to gain some degree of acceptance, Sindhi Hindus began to jettison these aspects of their culture, and also began to turning to the Hindu right to a greater degree, embracing Sanskritic customs and rituals. Hence the "Aryanizing" of Moenjodaro, and even the name "Mohan jo daro" interpreted as the 'Mound of Krishna'. All these developments further cemented the turning away from Sindh, now perceived as a "Muslim" country, which had no place for Sindhi Hindus, and from where they had been literally ejected. (This was later exacerbated by the Indo-Pak wars of 1965 and 1971, and the Kargil conflict of 1999, which turned Pakistan into an "enemy country" for many Hindus in India.)

There was a concomitant turning away from Sindhi language, culture and identity, which were perceived as belonging to the 'past'. However, this occurred in varying degrees. It appears to have occurred more in the younger generation that migrated, i.e. those who were teenagers or children in 1947. Older Sindhi Hindus had a deeper and more rooted sense of their ethnic identity. Similarly, upper-class Sindhi Hindus were more likely to turn away from the Sindhi language towards English and a more Westernized lifestyle.

\section{RAMIFICATIONS}

As mentioned earlier, Congress leaders had also encouraged this philosophy of downplaying Sindhi ethnicity. As a result, both Sindhi language and identity underwent a decline. In the initial years after Partition, several Sindhi-medium schools had been founded in India; similarly, the new generation of Sindhi writers (who had undergone the trauma of Partition) published numerous books, newspapers and magazines. After several decades of downplaying Sindhi ethnicity, the bulk of these Sindhi medium schools have shut down, as have many Sindhi language newspapers and magazines. Younger generations of Sindhis have also distanced themselves from their ethnic identity over the decades.

However, ethnic identity in a multi-ethnic society like India is also reinforced from the outside. Much as they may want, Sindhi Hindus cannot wish away their ethnic identity and become Nehru's idealized 'Indians'. Hence the writer Popati Hiranandani's observation: "I am also a refugee; I want to assimilate but the local population always reminds me that I am a refugee" (personal interview, November 1997).

As is the case with many communities, at times Sindhi Hindus too feel the need for a community history. The current trajectory of their political affiliations, however, has been moving more and more towards the Hindu right. As a result, when they search for a sense of community history, they largely reject the eleven centuries of Muslim rule in Sindh, and instead turn towards the single, most significant non-Muslim element of Sindhi history: Moenjodaro. This element has further been transmuted into an "Aryan bastion" or a "fountainhead of Hinduism" to give it far greater value, especially when judged by the yardsticks of right-wing Hinduism. In a concomitant vein, Muslims are depicted mainly as "oppressors". And thus Sindhi history is 'rewritten'. 
These trends dovetail with larger, more widespread trends towards right-wing Hinduism among Hindus in India today (and indeed, trends towards more hardened right-wing positions across the world). In other parts of India, there have been similar urges to 'rewrite' Indian history in a more saffronized vein, as for example, when textbooks in Rajasthan were amended in 2017 to state that Rana Pratap, and not Akbar, won the battle of Haldighati of $1576 .{ }^{15}$

\section{EPILOGUE}

However, technological innovations have revolutionized communications in an unprecedented way. Today, any person with access to the internet can create and upload a message or video which has the potential for "going viral" in a matter of minutes, that too on an international level. Consequently, Sindhis in India can connect with far greater ease with other Sindhis - Hindu or Muslim — in Pakistan, or elsewhere in the world. Over recent years, this has resulted in the wide dissemination (given the borderless nature of the internet) of messages, videos, etc which promote Sindhi language and identity among Sindhi Hindus. It is interesting to note that several of these videos — songs, skits and comic sketches — are created, or co-created by young Sindhis, in their twenties or even their teens. Further, email and What's App groups have sprung up, which connect Sindhis in both India and Pakistan.

To return to the song "Jiye munhinji Sindh" that started this essay, it remains a highly popular vehicle for promoting Sindhi identity. In recent years, there have been multiple renditions of this song posted on the internet, including pop and remix versions (which are likely to appeal to younger generations of Sindhis), and also videos of Sindhis dancing to this song; these videos have been viewed literally thousands of times. (Juriani 2012; Pahlajani and Udasi 2017). These videos also include one (with slightly modified lyrics), actually created by a Sindhi Muslim in Pakistan, which depicts Hindu-Muslim communal harmony among Sindhis (Mughal 2018). The song's multiple incarnations over the years are a testament to its enduring popularity. However, this also means that the selective 'remembering' of Sindh that it embodies continues to be perpetuated.

Clearly, the internet has provided Sindhis across the globe (and indeed all people) with innovative ways and means of recreating and disseminating new expressions of their identity, and sometimes even 'rewriting' their history. The story of this song continues, as does the parallel story of Sindhi ethnic identity.

Reviews sent to author: 30 November 2017

Revised paper accepted for publication: 20 February 2018

15 Incidentally, the Rajasthan Minister of State for primary and secondary education (then and now) was a Sindhi: Vasudev Devnani. 


\section{REFERENCES}

Aggarwal, Saaz. Sindh: Stories from a Vanished Homeland. Black-and-White Fountain, 2012.

Allen, Calvin H. "The Indian Merchant Community of Masqat." Bulletin of the School of Oriental and African Studies, University of London, 44: 1, 1981, pp. 39-53.

Balasubrahmanyan, Suchitra. "Partition and Gujarat: The Tangled Web of Religion, Caste, Community and Gender Identities." South Asia, 34: 3, 2011, pp. 460-484.

Bhagchandani, Bhagwan. Promoters and Preservers of Sindhiyat. Sheila Gopal Foundation, 2003.

Bharadwaj, Prakash. Sindhis Through the Ages. Worldwide Publishing Company, 1998. 2 vols.

Bhavnani, Nandita. The Making of Exile: Sindhi Hindus and the Partition of India. Tranquebar, 2014.

Borvin, Michel and Bhavna Rajpal. "From Udero Lal in Sindh to Ulhasnagar in Maharashtra: Partition and Memories Across Borders in the Tradition of Jhulelal." Partition and the Practice of Memory, edited by Churnjeet Mahn and Anne Murphy, Palgrave Macmillan, 2018, pp. 43-62.

Buxani, Ram. Taking the High Road. Motivate Publishing, 2003.

Chawla Paroo and Hiro Thakur. Choond Sindhi Kalaam ain Dohira. Pooja Publications, 1996.

Daswani Kavita. Kishinchand Chellaram: Sindhi Pathfinder. Linda Watkins \& Ass., 1998.

Dhameja, Dayal 'Asha'. Sindhi Saints. Himathsing B. Advani, 2002.

Gehani, Mohan. Brief Introduction: History of Sindh. Indian Institute of Sindhology, 2008.

Gidwani, Bhagwan S. Return of the Aryans. Penguin, 1994.

The March of the Aryans. Penguin, 2012.

Jawhrani, Ram. Global Sindhis: Inheritors of the Indus Valley Civilization. Sindhishaan, 2009.

JURIANI, Raj.”Jiye Muhinji Sindh", http://www.youtube.com/watch?v=inr-_cCUEQ0, Accessed 18 January 2018.

Kothari, Rita. "RSS in Sindh: 1942-48.” Economic and Political Weekly, 8-15 July 2006, pp. 30073013.

Kothari, Rita. The Burden of Refuge: The Sindhi Hindus of Gujarat. Orient Longman, 2007.

LAmbrick, h.T. The Census of India, 1941, volume XII, Sind. Manager of Publications, 1942.

Maknija Anju, Menka Shivdasani and Arjan 'Shad' Mirchandani. Freedom and Fissures. Sahitya Akademi, 1998.

Malkani, K.R. The Sindh Story. Sindhi Academy, 1997.

Markovits, Claude. The Global World of Indian Merchants, 1750-1947: Traders of Sind from Bukhara to Panama. Cambridge University Press, 2000.

Matlani, Prem. The Indus Empire: History of Sindh. Global Sindhi Council, 2015.

Motwani, Hari. Maati-a Manjh Mahi. Koonj Publications, 2002.

Mughal, Ahmed. “Jiye Muhinji Sindh.” http://www.youtube.com/watch?v=pH98hnmbXAs, Accessed on 29 January 2018

Nandy, Ashis. "Foreword". The Making of Exile: Sindhi Hindus and the Partition of India by Nandita Bhavnani, Tranquebar, 2014, pp. XV-XviII. 
Pahlajani, Jyotsna and Jatin Udasi."Jiye Muhinji Sindh", http://www.youtube.com/watch? v=AYOpzkxqlzs, Accessed 29 January 2018.

Prakash, Kala. Je Hinare Manjh Huran. 1987.

Shahani, Rita. Jite Munhinja Othiyada. Koonj Publications, 2003.

Sikayal, Arjan. Sindh jo Safarnamo. Sindhi Kitab Ghar, 2004.

Thakur, U.T. Sindhi Culture. Reprint: Sindhi Academy, Delhi, 1998.

Vaswani, K.N. We the Sindhi People. Sindhu Samaj, Delhi, 1998.

Vaswani, T.L. Sind and the Sindhis. Mira Publications, n.d. 